\title{
ANALISIS KEPERCAYAAN DALAM C2C E-COMMERCE TERHADAP KEPUTUSAN PEMBELIAN DAN DAMPAKNYA TERHADAP REPURCHASE PADA KASKUS
}

\author{
Hartiwi Prabowo; Darman; Enny Noegraheni \\ Management Department, School of Business Management, BINUS University \\ Jln. K. H. Syahdan No. 9, Palmerah, Jakarta Barat 11480 \\ Hartiwi2200@binus.ac.id
}

\begin{abstract}
The development of $\mathrm{C} 2 \mathrm{C}$ e-commerce business in Indonesia has grown quite rapidly. This phenomenon is motivated by such a rapid development of the Internet. In the Internet-based commerce transaction, the trust factor (trust) becomes so important because consumers tend to be more concerned if e-commerce merchants do not comply with the obligations of business transactions compared to conventional transaction. This study aims to determine the effect of trust on purchasing decisions and their impact on repeat purchases by customers in the buying and selling forum Kaskus site. The number of respondents are 200 people who have experienced in buying and selling on Kaskus site and this research model is tested using path analysis.The study states that the customers' trust variable has positive and significant impact on purchasing decisions, the variable purchase decisions has positive and significant effect on repeat purchase and customer trust has positive and significant impact on repeat purchase, but the magnitude of the effect becomes larger after the purchase decision (indirect effect ).
\end{abstract}

Kata kunci: kepercayaan, keputusan pembelian, pembelian ulang, situs Kaskus

\begin{abstract}
ABSTRAK
Perkembangan bisnis e-commerce C2C di Indonesia mengalami kenaikan pertumbuhan yang cukup tinggi. Fenomena ini dilatarbelakangi oleh perkembangan internet yang demikian pesat Pada transaksi perdagangan berbasis internet, faktor kepercayaan (trust) menjadi begitu penting karena konsumen cenderung lebih khawatir terhadap pelaku bisnis e-commerce tidak mematuhi kewajiban transaksinya dibandingkan dengan transaksi bisnis konvensional. Penelitian ini bertujuan untuk mengetahui pengaruh antara kepercayaan (trust) terhadap keputusan pembelian dan dampaknya terhadap pembelian ulang pelanggan di forum jual beli situs Kaskus. Jumlah responden sebanyak 200 orang yang pernah bertransaksi di situs Kaskus dan Model penelitian ini diuji menggunakan Path Analysis. Hasil penelitian menyatakan variabel Kepercayaan pelanggan berpengaruh positif dan signifikan terhadap keputusan pembelian, variabel keputusan pembelian berpengaruh positif dan signifikan terhadap pembelian ulang dan kepercayaan pelanggan berpengaruh positif dan signifikan terhadap pembelian ulang, namun besarnya pengaruh menjadi lebih besar setelah melalui keputusan pembelian (pengaruh tidak langsung).
\end{abstract}

Kata kunci: kepercayaan, keputusan pembelian, pembelian ulang, situs Kaskus 


\section{PENDAHULUAN}

Perkembangan internet telah demikian pesat dan telah menjadi suatu tren baru dan terus berkembang di dunia begitu juga Indonesia. Internet tidak hanya menjadi sarana mencari dan bertukar informasi tetapi juga sebagai sebuah media terus berkembang melalui inovasi yang teraplikasi dalam kehidupan. Potensi internet khususnya dalam bidang pemasaran sangatlah berarti. Salah satunya menghasilkan suatu pandangan mengenai perdagangan elektronik, khususnya perdagangan elektronik melalui internet yang umumnya dikenal sebagai Electronic Commerce (e-commerce), sebagai suatu bisnis dengan berbagai kemungkinan. (Rao, Salam dan Santos, 1998).

Indonesia pun tak luput dari perkembangan e-commerce. Transaksi perdagangan melalui internet atau e-commerce di Indonesia pada tahun 2009 sangat luar biasa, tercatat nilainya menembus angka Rp. 35 triliun. Hal ini diungkapkan Lembaga Riset Telematika Sharing Vision saat menggelar workshop State of The Art Global Electronic \& Mobile Micropayment \& Mobile Remittance di Royal Plaza, Singapura. Selain itu, berdasarkan rilis yang dikeluarkan oleh Forrester Research, pada tahun 2012 potensi pasar $e$-commerce secara global mencapai US\$ 172,9 miliar. Namun, ternyata penyedia layanan e-commerce di Indonesia baru mencapai 3\% sehingga peluang untuk memasuki bisnis $e$ commerce masih sangat besar (Forrester, US e-business overview, 2003-2008). Selain itu salah satu fenomena lainnya adalah harga akses internet yang menjadi jauh lebih murah dalan kurun waktu dua tahun terakhir, terlebih terobosan teknologi yang dapat mendorong para pengguna telepon genggam menggunakan internet dengan rata- rata US\$7.7 per bulan, sehingga dapat diperkirakan pengguna internet Indonesia pada tahun 2014 akan mencapai 150 juta (Mix, 2010).

Dari hasil riset yang dilakukan, Cheskin (1999) menjelaskan bahwa konsumen baru dalam $e$ commerce sering merasa bingung ketika berkunjung ke sebuah situs, di mana semua informasi di dalamnya baru dan tidak dikenal. Selain itu, ada kekhawatiran bahwa informasi yang konsumen berikan kepada situs akan disebarluaskan ke umum. Rasa tidak percaya membuat mereka yakin bahwa transaksi di e-commerce akan menghasilkan hasil yang tidak dapat diprediksi. Salah satunya adalah ketakutan akan gagalnya transaksi akibat penipuan. Perasaan bingung dan ketidakpastian mendorong kemunculan kebutuhan untuk mengontrol personal information. Tetapi kontrol personal information ini membutuhkan pengalaman penggunaan e-commerce itu sendiri. Mereka merasakan distrust dan ketidakamanan yang disebabkan ketidaktahuan pihak lawan transaksi mereka. Distrust tersebut terjadi di mana wadah transaksi yang digunakan dianggap tidak aman atau ada kekhawatiran mengenai seberapa aman personal information konsumen tidak tersebar kepada orang lain (Cheskin 1999).

Kejahatan melalui internet (cyberfraud/internetfraud) dalam berbagai bentuk, baik di Indonesia maupun di belahan dunia lain, masih menjadi ancaman bagi kelangsungan e-commerce. Menurut hasil riset pada tahun 2004 yang dilakukan oleh US Verisign, Indonesia dinyatakan berada di urutan pertama negara asal pelaku cyberfraud dan urutan ketiga berdasarkan volume setelah US dan Canada. Hasilnya menunjukkan bahwa sekitar 20\% dari total transaksi kartu kredit dari Indonesia di Indonesia adalah fraud.

Data diatas menunjukkan bahwa transaksi melalui e-commerce memiliki potensi resiko yang cukup tinggi. Tetapi mengapa transaksi e-commerce hingga saat ini masih berlangsung dan cenderung meningkat? Apakah manfaat yang diperoleh lebih besar daripada resikonya? Berkaitan dengan hal ini, Corbit et al (2003) telah melakukan penelitian dan hasilnya adalah partisipasi konsumen yang meningkat dalam e-commerce berkaitan langsung dengan pengalaman menggunakan web, orientasi pasar dan kepercayaan (trust).

Bangunan sistem e-commerce sebaik apapun pasti masih mengandung potensi resiko (risk). Sebagaimana penelitian yang dilakukan oleh Pavlou dan Gefen (2002), Corbit et al (2003), Kim dan Tadisina (2003), Mukherjee dan Nath (2003), dan peneliti yang lain dari sekian banyak faktor yang 
dapat mempengaruhi terjadinya transaksi melalui e-commerce, faktor kepercayaan (trust) menjadi faktor kunci. Banyak peneliti beragumentasi mengenai kepercayaan (trust) sebagai syarat untuk suksesnya e-commerce, hal ini terjadi karena konsumen merasa ragu untuk melakukan pembelian kecuali mereka percaya (trust) terhadap si penjual (Pavlou dan Gefen, 2002). Kepercayaan konsumen lebih penting dalam elektronik cyber dibandingkan dalam dunia transaksi tradisional. Hal ini terjadi karena beberapa karakteristik dari transaksi internet cyber, mereka tidak terlihat, tidak terbatas, dan terjadi setiap hari.

Oleh karena itu, kunci keberhasilan dari bisnis berbasis internet dibangun dari proses transaksi yang terpercaya di mana pelaku bisnis harus menciptakan suasana yang mampu membuat calon konsumen dapat merasa nyaman dan percaya diri untuk melakukan transaksi secara online (Grabosky, 2001). Karena kepercayaan (trust) dalam konteks transaksi e-commerce sangat berperan penting, maka mengidentifikasi variabel-variabel yang mempengaruhi pembentukan tingkat kepercayaan (trust) konsumen harus dilakukan dalam konteks transaksi melalui internet. Selain itu, harus dilakukan pula pengidentifikasian pengaruh pembentukan tingkat kepercayaan (trust) terhadap keputusan pembelian konsumen dalam konteks e-commerce.

Dalam penelitian ini, peneliti memilih Kaskus sebagai contoh forum komunitas online yang telah mengaplikasikan C2C e-commerce. Perkembangan e-commerce di Kaskus ditandai dengan diciptakannya Forum Jual Beli atau FJB Kaskus sebagai wadah bagi para pelaku e-commerce. Kaskus menganggap bahwa e-commerce merupakan suatu hal yang potensial dan merupakan masa depan dari situs tersebut, sehingga mereka mulai mengambangkan Forum Jual Beli (FJB) sejak 2008. Hal ini sejalan dengan pengenalan Kaspay sejak 2010 sebagai sarana bertransaksi yang aman yang digunakan dalam FJB Kaskus dengan tujuan agar kaskus dapat mendapatkan keuntungan dari besarnya jumlah transaksi yang terjadi di Forum Jual Beli. Walau secara statistik belum ada yang pernah menghitung secara pasti total nilai transaksi harian, bulanan maupun tahunan.

Kepopuleran Kaskus sebagai forum dan tempat untuk melakukan transaksi e-commerce melalaui fitur Forum Jual Beli (FJB) mewajibkan Kaskus mampu membentuk kepercayaan bagi para pengguna e-commerce di Forum Jual Beli (FJB) Kaskus. Jumlah anggota yang besar mendorong para pelaku pribadi, yang memiliki minat sama tapi tidak mengenal satu sama lain, untuk melakukan transaksi e-commerce di Forum Jual Beli. Bertransaksi dengan pelaku pribadi yang tidak dikenal dapat menimbulkan rasa ketidakpercayaan dan menyebabkan gagal transaksi antar kedua belah pihak pengguna fitur. Oleh karena itu, kepercayaan dalam melakukan transaksi e-commerce perlu di identifikasikan dan dipelajari untuk mendorong pengguna e-commerce mengetahui bagaimana cara melakukan transaksi e-commerce secara aman dan sukses. Selain itu, harus dilakukan pula pengidentifikasian pengaruh tingkat kepercayaan (trust) terhadap keputusan pembelian konsumen dan repurchase dalam konteks e-commerce.

Penelitian ini bertujuan untuk (1) Menganalisis pengaruh kepercayaan pelanggan dalam Ecommerce C2C terhadap keputusan pembelian di Forum Jual Beli (FJB) Kaskus. (2) Menganalisis pengaruh keputusan pembelian terhadap repurchase di Forum Jual Beli (FJB) Kaskus. (3) Menganalisis pengaruh kepercayaan pelanggan dalam E-commerce $\mathrm{C} 2 \mathrm{C}$ terhadap keputusan pembelian dan dampaknya terhadap repurchase di Forum Jual Beli (FJB) Kaskus

\section{C2C E-commerce}

Jengwu, et.al (2009) menyebutkan bahwa C2C E-commerce sebagai sebuah komunitas virtual, wadah bagi customer to customer dalam E-commerce dan dapat menjalankan fungsi sosial dan fungsi bisnis dengan baik. Dalam perspektif komunitas sosial, wadah virtual ini akan dapat mendorong interaksi antar individu. Anggota yang tergabung akan dapat mengembangkan pertemanan, sehingga akan mempunyai ketertarikan yang sama dan bertukar informasi bahkan melakukan perdagangan (Hagel dan Amstrong, 1997 dalam Chen et. al, 2009) 
Schubert and Ginsburg (2000) dalam Chen et.al. (2009) berpendapat bahwa bila ditinjau dari perspektif bisnis, komunitas virtual terbentuk dari perdagangan yang sedang berjalan dan wadah pemasaran (Kaskus) yang memungkinkan terjadinya interaksi komersial antara penjual, pembeli dan penengah atau penyalur, sehingga akan terjadi transaksi antara anggota komunitas virtual tersebut.

Walaupun penggunaan E-commerce terlihat menjanjikan, Chen et.al (2009) mengemukakan bahwa komunitas virtual terkesan masih informal dan nilai bisnis mereka masih didasarkan dari keinginan subjektif secara konstan untuk menggunakan sarana komunitas virtual sebagai tempat pertukaran informasi dan transaksi bisnis. Meskipun demikian menurut Hagel dan Armstrong (1997), anggota komunitas virtual dapat dibedakan dengan pembelanja online melalui toko online konvensional karena adnya grup sosial yang mampu menyeimbangkan kekuatan yang mengasosiasikan antara penjual dan konsumen melalui adanya informasi dan pertukaran informasi.

\section{Online Trust}

Perbedaan antara online trust dengan off-line trust menurut Sung - Joon Yoon (2002) adalah adanya jarak fisik yang nyata antara pembeli dan penjual dengan ketiadaan sales people, serta adanya pemisahan antara pembeli dan produk. Kepercayaan konsumen dalam hal penggunaan data pribadi dan hukum yang akan melindungi mereka menjadi faktor utama yang turut mempengaruhi tingkat kepercayaan mereka terhadap sebuah situs.

Kaasinen (2005) menyampaikan bahwa kepercayaan online adalah cara penggunaan sebuah situs oleh pengguna di mana pengguna bisa mengandalkan informasi dan jasa yang disediakan serta kerahasiaan penggunaan data pribadi mereka. Pemakaian sebuah situs atau forum melibatkan banyak penggunaan fitur yang disediakan situs yang banyak melibatkan pertukaran informasi, dan pengisian data pribadi yang diberikan oleh calon konsumen yang akan menggunakan fitur di situs tersebut. Isu etis mengenai informasi individu harus mendapat perhatian yang lebih terutama penjaminan privasi pengguna situs untuk melaksanakan transaksi.

Penelitian ini mereplikasikan model trust yang dikembangkan oleh Jones dan Leonard (2008), menurut Jones dan Leonard (2008) trust dalam C2C e-commerce dipengaruhi oleh dua faktor yaitu internal dan eksternal. Faktor internal terdiri dari Natural Propensity to Trust (kemampuan seseorang untuk mempercayai), dan Perception of Website Quality (persepsi seseorang dalam menilai kualitas dari sebuah situs). Sedangkan faktor eksternal terdiri dari Other Trust of Buyer or Seller (kepercayaan yang diberikan pihak lain kepada penjual atau pembeli) dan Third Party Recognition (pengakuan yang diberikan oleh pihak ketiga).

\section{Pengertian Keputusan Pembelian}

Menurut Winardi (2001) keputusan pembelian konsumen merupakan titik puncak suatu pencarian dari proses evaluasi. Sedangkan menurut Peter dan Olson (2000) keputusan pembelian konsumen adalah proses pengintegrasian yang dikombinasikan untuk mengevaluasi dua atau lebih perilaku alternatif dan memilih salah satu diantaranya. Sedangkan menurut Kotler dan Amstrong (2004) mengemukakan bahwa keputusan pembelian adalah tahap proses keputusan dimana konsumen secara aktual melakukan pembelian produk. Menurut Kotler (2008) konsumen melalui lima tahapan tersebut dalam setiap pembelian, jelasnya proses pembelian dimulai jauh sebelum pembelian aktual dan terus berlangsung lama sesudahnya. Pelaku bisnis perlu memusatkan perhatian pada proses pembelian dan bukan pada keputusan pembelian saja.

\section{Pembelian Ulang}

Menurut Hawkins et.al. (2007) pembelian kembali adalah kegiatan membeli kembali yang dilakukan oleh konsumen terhadap suatu produk dengan merek yang sama tanpa diikuti oleh perasaan 
yang berarti terhadap produk tersebut. Terdapat dua kemungkinan yang dapat menyebabkan seseorang melakukan pembelian kembali suatu produk. Pertama, konsumen merasa puas dengan pembelian yang mereka lakukan, kedua pelanggan merasa tidak puas, tetapi mereka tetap melakukan pembelian kembali. Untuk kemungkinan kedua ini biasanya disebabkan mereka menganggap biaya yang harus mereka keluarkan untuk mencari, mengevaluasi, dan mengadopsi produk dengan merek lain (switching cost) terlalu tinggi.

Penelitian ini dapat digambarkan sebagai berikut :

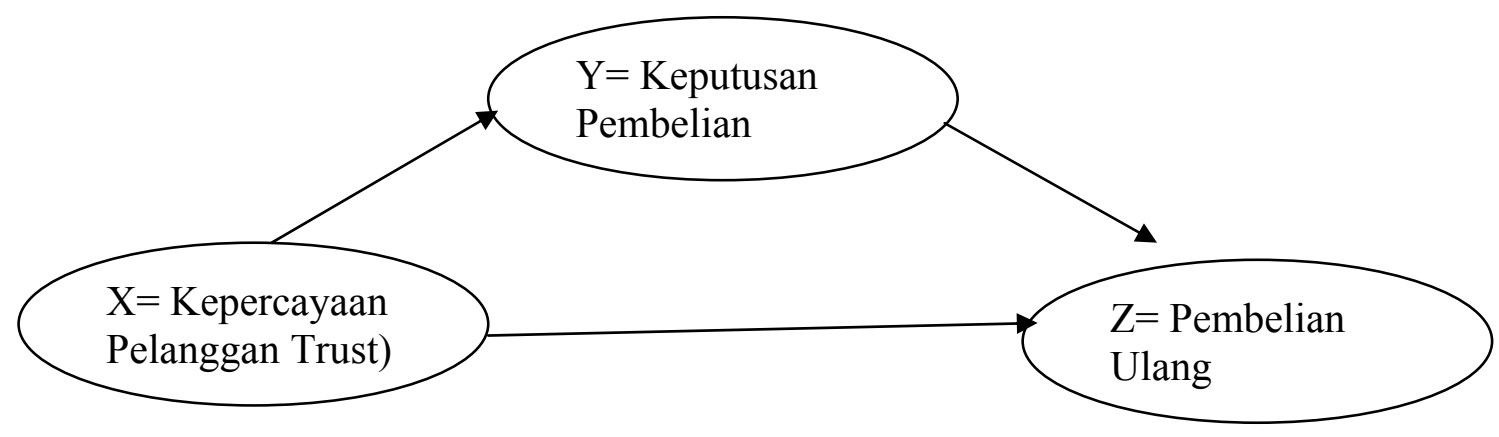

Gambar 1 Kerangka pemikiran

\section{METODE}

Unit analisis dalam penelitian ini adalah individu, yaitu para konsumen yang membeli produk di Forum Jual Beli Kaskus. Time horizon yang digunakan adalah Cross-sectional, yaitu sebuah studi yang dapat dilakukan dengan data yang hanya sekali dikumpulkan mungkin selama periode harian, mingguan atau bulanan dalam jangka menjawab penelitian (Uma Sekaran, 2007). Berikut ini adalah desain penelitian yang tertera pada tabel 1 dibawah ini :

Tabel 1 Desain penelitian

\begin{tabular}{|c|c|c|c|c|}
\hline Tujuan & \multicolumn{4}{|c|}{ Desain penelitian } \\
\hline & Jenis Penelitian & Metode yang digunakan & Unit Analisis & Time horizon \\
\hline $\mathrm{T} 1$ & Deskriptif asosiatif & Deskriptif Survey & $\begin{array}{l}\text { Individu -konsumen } \\
\text { di Jual beli Kaskus }\end{array}$ & Cross sectional \\
\hline $\mathrm{T} 2$ & Deskriptif asosiatif & Deskriptif Survey & $\begin{array}{l}\text { Individu -konsumen } \\
\text { di Jual beli Kaskus }\end{array}$ & Cross sectional \\
\hline T3 & Deskriptif asosiatif & Deskriptif Survey & $\begin{array}{l}\text { Individu - konsumen } \\
\text { di Jual beli Kaskus }\end{array}$ & Cross sectional \\
\hline
\end{tabular}




\section{Teknik Pengambilan sampel}

Populasi di dalam penelitian ini adalah orang yang menjadi anggota Kaskus dan pernah melakukan transaksi di Forum Jual Beli (FJB) Kaskus. Dalam penelitian ini sampel diambil sebanyak 200 responden. Hal ini berdasarkan Malhotra (2010) yang menyatakan bahwa sampel untuk observasi sebanyak 200-500 responden.

Tabel 2 Tabel Operasionalisasi Variabel Penelitian

\begin{tabular}{|c|c|c|c|c|}
\hline Variabel & Dimensi & Konsep & Indikator & Skala \\
\hline $\begin{array}{l}\text { Kepercayaan } \\
\text { Pelanggan (Trust) }\end{array}$ & $\begin{array}{l}\text { - Perception of Website } \\
\text { Quality (PWSQ) }\end{array}$ & $\begin{array}{l}\text { Persepsi seseorang } \\
\text { terhadap kualitas situs } \\
\text { web, yang akan } \\
\text { mempengaruhi } \\
\text { seseorang percaya di } \\
\text { C2C e-commerce. }\end{array}$ & 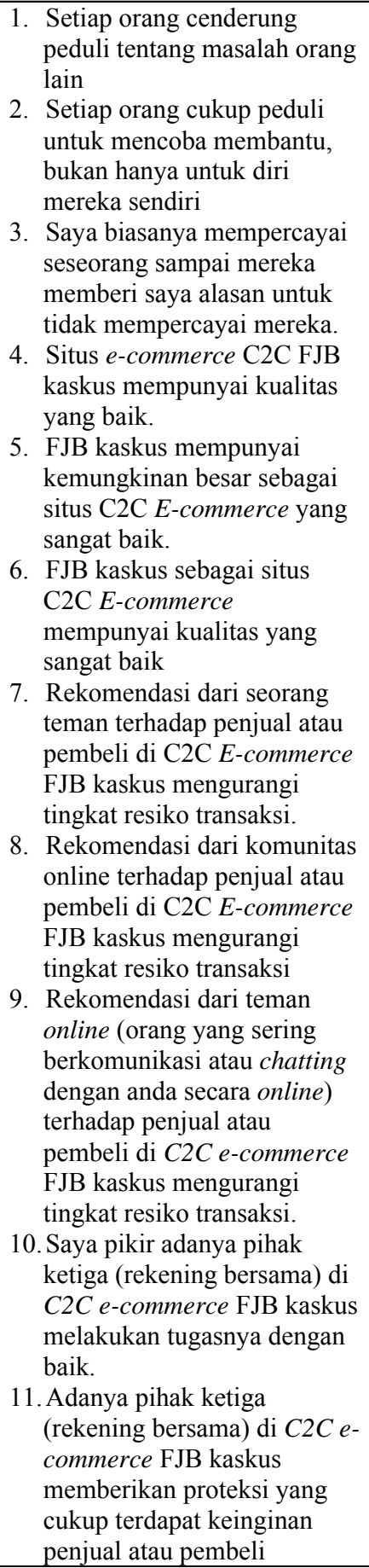 & $\begin{array}{l}\text { Skala likert } \\
1-5\end{array}$ \\
\hline
\end{tabular}




\begin{tabular}{|c|c|c|c|}
\hline & $\begin{array}{l}\text { - Third Party } \\
\text { Recognition (TPR) }\end{array}$ & $\begin{array}{l}\text { Pengakuan dari pihak } \\
\text { ketiga oleh pembeli / } \\
\text { penjual akan } \\
\text { mempengaruhi } \\
\text { kepercayaan orang di } \\
\text { C2C e-commerce }\end{array}$ & \\
\hline $\begin{array}{l}\text { Keputusan } \\
\text { pembelian }\end{array}$ & Membeli atau tidak & $\begin{array}{l}\text { Prilaku seseorang dalam } \\
\text { mangambil keputusan } \\
\text { untuk membeli pada } \\
\text { C2C } \\
\text { e-commerce }\end{array}$ & $\begin{array}{l}\text { 12. Saya membeli produk pada } \\
\text { FJB Kaskus, karena variasi } \\
\text { produk } \\
\text { 13. Saya membeli produk pada } \\
\text { FJB Kaskus, karena harga. } \\
\text { 14. Saya membeli produk pada } \\
\text { FJB Kaskus, karena } \\
\text { pelayanan yang cepat }\end{array}$ \\
\hline $\begin{array}{l}\text { Pembelian Ulang } \\
\text { (repurchase) }\end{array}$ & $\begin{array}{l}\text { Pembelian ulang atau } \\
\text { tidak }\end{array}$ & $\begin{array}{l}\text { Tindakan yang } \\
\text { dilakukan untuk } \\
\text { mengulangi pembelian } \\
\text { produk pada } \mathrm{C} 2 \mathrm{C} \text { - } \\
\text { commerce }\end{array}$ & $\begin{array}{l}\text { 15. Saya akan melakukan } \\
\text { pembelian ulang pada FJB } \\
\text { Kaskus, karena yakin pada } \\
\text { pengalaman masa lalu. } \\
\text { 16. Saya akan } \\
\text { merekomendasikan layanan } \\
\text { yang ada kepada orang lain. } \\
\text { 17. Saya tidak akan berpindah ke } \\
\text { situs lain. Blackwell (2001) }\end{array}$ \\
\hline
\end{tabular}

\section{Teknik Analisis Data}

Setelah data dikumpulkan, maka dilakukan uji validitas dan reliabilitas. Setelah itu dilanjutkan uji normalitas terhadap data yang ada. Setelah data dipastikan normal, valid, dan reliabel, maka dilakukan analisis dengan menggunakan teknik analisis Path.

\section{HASIL DAN PEMBAHASAN}

\section{Hasil Path Analisis}

Pengujian Sub-struktur 1: Analisis Pengaruh Kepercayaan Pelanggan terhadap Keputusan Pembelian

Tabel 2 Model Summary Sub-struktur 1 Model Summary ${ }^{\mathrm{b}}$

\begin{tabular}{|l|r|r|r|c|}
\hline Model & \multicolumn{1}{|c|}{$\mathrm{R}$} & R Square & \multicolumn{1}{c|}{$\begin{array}{c}\text { Adjusted R } \\
\text { Square }\end{array}$} & $\begin{array}{c}\text { Std. Error of the } \\
\text { Estimate }\end{array}$ \\
\hline 1 & $.535^{\mathrm{a}}$ & .286 & .282 & .60433 \\
\hline
\end{tabular}

a. Predictors: (Constant), Kepercayaan_Pelanggan

b. Dependent Variable: Keputusan Pembelian

Sumber: Output SPSS - Hasil Pengolahan Data, 2013 
Tabel 3 ANOVA Sub-struktur 1

ANOVA $^{\mathrm{b}}$

\begin{tabular}{|ll|r|r|r|r|r|}
\hline Model & & Sum of Squares & df & Mean Square & F & \multicolumn{1}{c|}{ Sig. } \\
\hline 1 & Regression & 28.930 & 1 & 28.930 & 79.214 & $.000^{\mathrm{a}}$ \\
& Residual & 72.311 & 198 & .365 & & \\
& Total & 101.241 & 199 & & & \\
\hline
\end{tabular}

a. Predictors: (Constant), Kepercayaan Pelanggan

b. Dependent Variable: Keputusan Pembelian

Tabel 4 Coefficients Sub-struktur 1

Coefficients $^{\mathrm{a}}$

\begin{tabular}{|c|c|c|c|c|c|c|}
\hline \multirow{2}{*}{\multicolumn{2}{|c|}{ Model }} & \multicolumn{2}{|c|}{ Unstandardized Coefficients } & \multirow{2}{*}{$\begin{array}{c}\begin{array}{c}\text { Standardized } \\
\text { Coefficients }\end{array} \\
\text { Beta }\end{array}$} & \multirow[b]{2}{*}{$\mathrm{t}$} & \multirow[b]{2}{*}{ Sig. } \\
\hline & & B & Std. Error & & & \\
\hline & (Constant) & 1.192 & .320 & & 3.723 & .000 \\
\hline & $\mathrm{X}$ & .692 & .078 & .535 & 8.900 & .000 \\
\hline
\end{tabular}

a. Dependent Variable: Y (Keputusan Pembelian)

Sumber: Output SPSS - Hasil Pengolahan Data, 2013

\section{Hipotesis:}

Ho: Variabel Kepercayaan Pelanggan tidak berpengaruh secara signifikan terhadap variabel Keputusan Pembelian.

Ha : Variabel Kepercayaan Pelanggan berpengaruh secara signifikan terhadap variabel Keputusan Pembelian

Dasar pengambilan keputusan adalah jika nilai probabilitas lebih kecil daripada nilai Sig. $(0.05<$ Sig.), maka Ho diterima dan Ha ditolak, artinya tidak signifikan. Jika nilai probabilitas lebih besar daripada atau sama dengan nilai Sig. (0.05 $\geq$ Sig.), maka Ho ditolak dan Ha diterima, artinya signifikan.

Dari hasil uji signifikansi pada tabel 3 diperoleh Sig. yang bernilai 0.000. Jika dibandingkan dengan $\alpha=0.05$, maka $0.05 \geq$ Sig. $(0.05 \geq 0.000$.), maka dapat ditarik kesimpulan bahwa Ho ditolak dan Ha diterima yang artinya signifikan dan menunjukkan bahwa terdapat pengaruh atau kontribusi antara variabel Kepercayaan Pelanggan secara signifikan terhadap variabel Keputusan Pembelian.

Besarnya pengaruh variabel $\mathrm{X}$ terhadap $\mathrm{Y}$ dapat diketahui dengan melihat $R$ Square $\left(\mathrm{R}^{2}\right)$ pada tabel 2. yang memiliki nilai sebesar 0.286. Hal ini menunjukkan bahwa pengaruh variabel Kepercayaan Pelanggan terhadap variabel Keputusan Pembelian secara simultan adalah sebesar $28,6 \%$. Sementara, sisanya sebesar $71,4 \%$ dipengaruhi oleh faktor lain. Besarnya koefisien jalur bagi variabel lain diluar penelitian yang mempengaruhi dapat dihitung melalui rumus berikut:

$$
\rho_{\mathrm{y}} \varepsilon_{1}=\sqrt{\left(1-\mathrm{R}^{2}\right)}=0.845
$$


Jadi, persamaan struktural untuk sub-struktur 1 adalah sebagai berikut:

$$
\begin{aligned}
& Y=\rho_{y x} X+\rho_{y} \varepsilon_{1} \\
& Y=0.535 X+0.845
\end{aligned}
$$

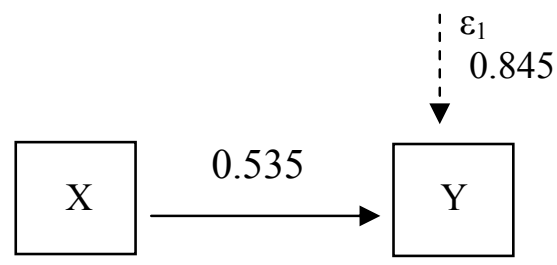

Gambar 2 Sub-struktur 1 setelah pengujian beserta Koefisien Jalur Sumber: Penulis, 2013

\section{Pengujian Sub-struktur 2: Analisis Pengaruh Kepercayaan Pelanggan dan Keputusan Pembelian terhadap Pembelian Ulang}

Tabel 5 Model Summary Sub-struktur Model Summary ${ }^{\mathrm{b}}$

\begin{tabular}{|l|r|r|r|r|}
\hline Model & \multicolumn{1}{|c|}{$\mathrm{R}$} & R Square & Adjusted R Square & $\begin{array}{c}\text { Std. Error of the } \\
\text { Estimate }\end{array}$ \\
\hline 1 & $.717^{\mathrm{a}}$ & .514 & .510 & .46884 \\
\hline
\end{tabular}

a. Predictors: (Constant), Y, X

b. Dependent Variable: $Z$

Sumber: Output SPSS - Hasil Pengolahan Data, 2013

Tabel 6 ANOVA Sub-struktur 2

ANOVA $^{\mathrm{b}}$

\begin{tabular}{|ll|r|r|r|r|r|}
\hline Model & & Sum of Squares & df & Mean Square & F & \multicolumn{1}{c|}{ Sig. } \\
\hline 1 & Regression & 45.889 & 2 & 22.944 & 104.381 & $.000^{\text {a }}$ \\
& Residual & 43.303 & 197 & .220 & & \\
& Total & 89.192 & 199 & & & \\
\hline
\end{tabular}

a. Predictors: (Constant), Y, X

b. Dependent Variable: Z

Sumber: Output SPSS - Hasil Pengolahan Data, 2013

\section{Hipotesis:}

Ho : Variabel Kepercayaan Pelanggan dan variabel Keputusan Pembelian tidak berpengaruh secara bersama-sama terhadap variabel Pembelian Ulang.

Ha : Variabel Kepercayaan Pelanggan dan variabel Keputusan Pembelian berpengaruh secara bersama-sama terhadap variabel Pembelian Ulang. 
Dasar pengambilan keputusan adalah jika nilai probabilitas lebih kecil daripada nilai Sig. $(0.05<$ Sig. $)$, Ho diterima dan Ha ditolak, artinya tidak signifikan. Jika nilai probabilitas lebih besar daripada atau sama dengan nilai Sig. (0.05 $\geq$ Sig.), maka Ho ditolak dan Ha diterima, artinya signifikan.

Dari hasil uji signifikansi pada tabel 6 diperoleh Sig. Sebesar 0.000. Jika dibandigkan dengan $\alpha=0.05$, maka $0.05 \geq$ Sig. $(0.05 \geq 0.000$. $)$ yang artinya Ho ditolak dan Ha diterima, yang menunjukkan bahwa terdapat pengaruh antara variabel Kepercayaan Pelanggan dan variabel Keputusan Pembelian berpengaruh secara simultan dan signifikan terhadap variabel Pembelian Ulang.

Besarnya pengaruh variabel Kepercayaan Pelanggan dan variabel Keputusan Pembelian terhadap variabel Pembelian Ulang dapat diketahui dengan melihat $R$ Square $\left(\mathrm{R}^{2}\right)$ pada tabel 5 . memiliki nilai sebesar 0.514. Hal ini menunjukkan bahwa pengaruh variabel Kepercayaan Pelanggan dan variabel Keputusan Pembelian terhadap variabel Pembelian Ulang secara simultan adalah sebesar $51,4 \%$. Sementara, sisanya sebesar 48,6\% dipengaruhi oleh faktor lain. Besarnya koefisien jalur bagi variabel lain diluar penelitian yang mempengaruhi dapat dihitung melalui rumus berikut:

$$
\begin{aligned}
\rho_{\mathrm{y}} \varepsilon_{2} & =\sqrt{\left(1-\mathrm{R}^{2}\right)} \\
& =0.697
\end{aligned}
$$

Tabel 7 Coefficients Sub-struktur 2

\begin{tabular}{|c|c|c|c|c|c|c|}
\hline \multirow{2}{*}{\multicolumn{2}{|c|}{ Model }} & \multicolumn{2}{|c|}{ Unstandardized Coefficients } & \multirow{2}{*}{$\begin{array}{c}\text { Standardized } \\
\text { Coefficients }\end{array}$} & \multirow[b]{2}{*}{$\mathrm{t}$} & \multirow[b]{2}{*}{ Sig. } \\
\hline & & B & Std. Error & & & \\
\hline \multirow[t]{3}{*}{1} & (Constant) & .718 & .257 & & 2.792 & .006 \\
\hline & $\mathrm{X}$ & .292 & .071 & .240 & 4.087 & .000 \\
\hline & $\mathrm{Y}$ & .525 & .055 & .560 & 9.527 & .000 \\
\hline
\end{tabular}

Coefficients $^{\mathrm{a}}$

a. Dependent Variable: $Z$

\section{Pengujian secara individual antara variabel Kepercayaan Pelanggan dan variabel Pembelian Ulang.}

\section{Hipotesis:}

Ho: Variabel Kepercayaan Pelanggan tidak berpengaruh secara signifikan terhadap variabel Pembelian Ulang.

Ha : Variabel Kepercayaan Pelanggan berpengaruh secara signifikan terhadap variabel Pembelian Ulang.

Dasar pengambilan keputusan adalah jika nilai probabilitas lebih kecil daripada nilai Sig. $(0.05<$ Sig.), maka Ho diterima dan Ha ditolak, artinya tidak signifikan. Jika nilai probabilitas lebih besar daripada atau sama dengan nilai Sig. (0.05 $\geq$ Sig.), maka Ho ditolak dan Ha diterima, artinya signifikan.

Dari tabel 7. diketahui bahwa nilai variabel Kepercayaan pelanggan memiliki nilai Sig sebesar 0.000 , Jika dibandigkan dengan $\alpha=0.05$, maka $0.05 \geq$ Sig. $(0.05 \geq 0.000)$ maka Ho ditolak dan Ha diterima yang artinya signifikan. Dengan demikian, dapat ditarik kesimpulan bahwa variabel Kepercayaan Pelanggan berkontribusi secara signifikan terhadap variabel Pembelian Ulang. 


\section{Pengujian secara individual antara variabel Keputusan Pembelian dan variabel Pembelian Ulang}

\section{Hipotesis:}

Ho: Variabel Keputusan pembelian tidak berpengaruh secara signifikan terhadap variabel Pembelian Ulang.

Ha : Variabel Keputusan pembelian berpengaruh secara signifikan terhadap variabel Pembelian Ulang.

Dasar Pengambilan Keputusan adalah Jika nilai probabilitas lebih kecil daripada nilai Sig. $(0.05<$ Sig.), maka Ho diterima dan Ha ditolak, artinya tidak signifikan. Jika nilai probabilitas lebih besar daripada atau sama dengan nilai Sig. $(0.05 \geq$ Sig.), maka Ho ditolak dan Ha diterima, artinya signifikan.

Dari tabel 7. diketahui bahwa variabel Keputusan Pembelian memiliki nilai Sig. sebesar 0.000 . Jika dibandigkan dengan $\alpha=0.05$, maka $0.05 \geq$ Sig. $(0.05 \geq 0.000)$ maka Ho ditolak dan Ha diterima yang artinya signifikan. Dengan demikian, dapat ditarik kesimpulan bahwa variabel Keputusan Pembelian berpengaruh secara signifikan terhadap variabel Pembelian Ulang.

Kerangka hubungan antara jalur Kepercayaan Pelanggan terhadap Pembelian Ulang dan Keputusan Pembelian terhadap Pembelian Ulang dapat dibuat melalui persamaan struktural sebagai berikut:

$$
\begin{aligned}
& Z=\rho_{z x} X+\rho_{z y} Y+\rho_{z}{ }^{\varepsilon 2} \\
& Z=0,240 X+0.560 Y+0.697
\end{aligned}
$$

Dari tabel 7. diketahui masing-masing koefisien jalur tersebut adalah sebagai berikut:

Koefisien Jalur X terhadap Z $\left(\rho_{z x}\right)=0.240$

Koefisien Jalur Y terhadap Z $\left(\rho_{z y}\right)=0.560$

Dengan model yang masih tetap sama dengan gambar 3. namun disajikan dengan nilai koefisiensi jalur yang telah diperoleh melalui analisa jalur, model Sub-Struktual 2 menjadi:

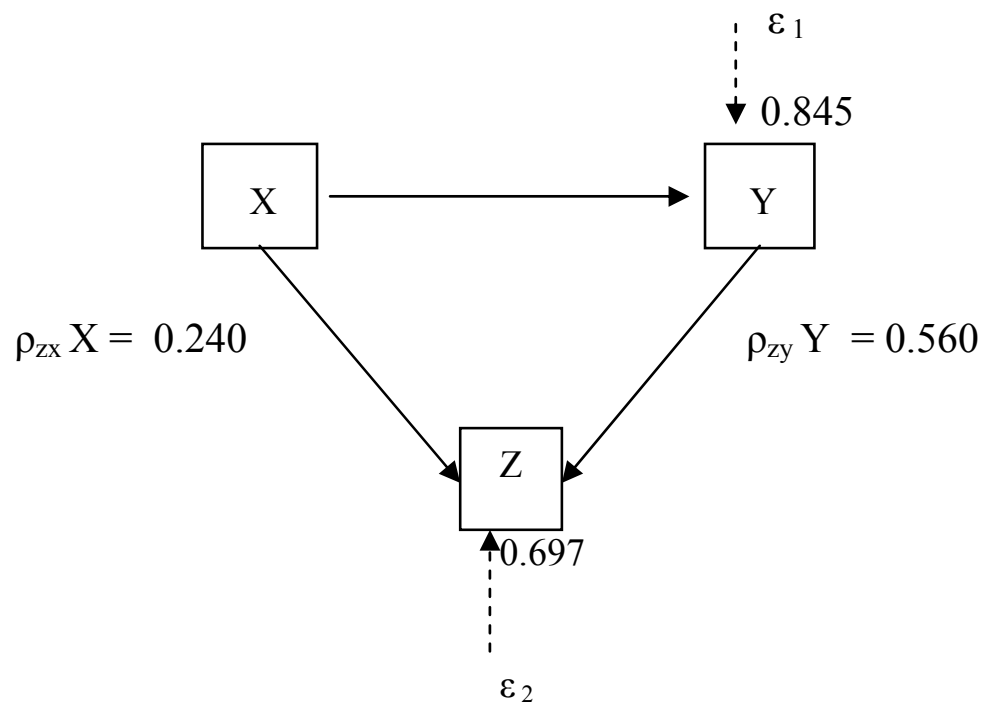

Gambar 3 Sub-struktur 2 setelah pengujian beserta Koefisien Jalur Sumber: Hasil Pengolahan Data, 2013 
Dengan ini analisa Sub-Stuktural 1 dan Sub-Struktural 2 telah selesai, maka dapat digambarkan struktur hubungan secara lengkap, yakni hubungan antara variabel $\mathrm{X}, \mathrm{Y}$, dan $\mathrm{Z}$ yang memiliki persamaan struktural.

Persamaan Sub-Struktural $1 \quad \mathrm{Y}=0.535 \mathrm{X}+0.845$

Persamaan Sub-Struktural $2 \quad Z=0,240 X+0.560 Y+0.697$

Tabel 8 Rangkuman Analisis Jalur

\begin{tabular}{cccccc}
\hline \multirow{2}{*}{ Variabel } & $\begin{array}{c}\text { Koefisien } \\
\text { Jalur }\end{array}$ & $\begin{array}{c}\text { Kategori } \\
\text { Pengaruh }\end{array}$ & Langsung & Tidak Langsung & Total \\
\hline X terhadap Y & 0.535 & Kuat & 0.535 & - & 0.535 \\
X terhadap Z & 0.240 & Sedang & 0.240 & $0.535 \times 0.560=0.300$ & 0.540 \\
Y terhadap Z & 0.560 & Kuat & 0.560 & - & 0.560 \\
$\varepsilon_{1}$ & 0.845 & - & 0.845 & - & 0.845 \\
$\varepsilon_{2}$ & 0.697 & - & 0.697 & - & 0.697 \\
\hline \multirow{2}{*}{ Xdan Y terhadap Z } & \multicolumn{2}{c}{ R Square = Rz(x,y) Tabel 5.14. Model Summary Sub-Struktural 2 } & 0.514 \\
\hline
\end{tabular}

Sumber: Hasil Pengolahan Data, 2013

\section{PEMBAHASAN}

Setelah semua data diolah dan hasil penelitian telah diketahui, maka dapat diketahui bahwa Kepercayaan pelanggan dan keputusan pembelian berpengaruh secara simultan terhadap pembelian ulang pada konsumen forum jual beli Kaskus. Hal ini mendukung teori Zhang et al (2011) yang menyatakan bahwa faktor online relationship quality dan perceived website usability sebagai faktorfaktor yang mendorong terjadinya repurchase intention. Online relationship quality merupakan faktor hubungan (kepercayaan) yang terbentuk antara vendor dan konsumen dalam online shopping. Hasil studi dari Zhang menunjukkan bahwa terdapat korelasi yang positif antara online relationship quality dan perceived website usability terhadap repurchase intention. Selain itu kepercayaan pelanggan merupakan dasar yang diperlukan perusahaan untuk mempertahankan pelanggan yang sudah ada. Hal ini mendukung penelitian yang dilakukan oleh Sarwar et al (2012). Hal ini juga mendukung teori Rousseau et al (Akbar dan Perves, 2009) yang menyatakan bahwa kepercayaan sanagt penting untuk membangun dan mempertahankan hubungan pelanggan jangka panjang. Menurut Morgan dan Hunt (Danesh et al 2012) menyatakan bahwa kepercayaan pelanggan cederung menjadi pendorong kuat terhadap pembelian ulang.

\section{SIMPULAN}

Penelitian ini menyimpulkan bahwa kepercayaan pelanggan berpengaruh positif dan signifikan terhadap keputusan pembelian dengan nilai sebesar 0,535. Keputusan pembelian berpengaruh positif dan signifikan terhadap pembelian ulang dengan nilai 0,560. Kepercayaan pelanggan berpengaruh positif dan signifikan secara langsung terhadap pembelian ulang dengan nilai 0,20 dan berpengaruh secara tidak langsung (setelah terjadi keputusan pembelian) dengan nilai 0,540. 
Hasil penelitian ini memberikan sumbangan saran untuk peningkatan kepercayaan pelanggan di situs FJB Kaskus. Melalui kuesioner yang disebarkan, nilai rata-rata terkecil diperoleh dengan pernyataan pada dimensi Natural Propensityto Trust (Kecenderungan alami seseorang untuk percaya akan mempengaruhi kepercayaan seseorang di $\mathrm{C2C}$ e-commerce) yang menyebutkan bahwa "Setiap orang akan mempercayai orang lain sampai mereka memberikan alasan untuk tidak mempercayainya" $(3,73)$ dan pernyataan "Setiap orang peduli terhadap permasalahan orang lain" $(3,88)$.

Saran yang dapat dijabarkan peneliti untuk meningkatkan kepercayaan pelanggan antara lain: (a) Disain situs dibuat lebih menarik dan user friendly. (b) Menyediakan forum interaktif bagi interaksi antar konsumen, dimana konsumen dapat menciptakan thread tersendiri dan saling berkomunikasi. Saran untuk peningkatan keputusan pembelian: Melalui kuesioner yang disebarkan, sedangkan nilai rata-rata terkecil diperoleh oleh pernyataan yang menyebutkan bahwa "Saya membeli produk pada FJB Kaskus, karena produk yang ditawarkan bervariasi" $(3,71)$. Saran yang diberikan hendaknya FJB Kaskus lebih bervariasi baik produk maupun merek yang ditawarkan. Saran untuk peningkatan pembelian ulang pelanggan, melalui kuesioner yang disebarkan nilai rata-rata terkecil diperoleh oleh pernyataan menyebutkan bahwa "Saya akan melakukan pembelian ulang pada FJB Kaskus karena pengalaman masa lalu" $(3,69)$ Nampak bahwa shopping value yang diterima konsumen terutama dari segi pengalaman masa lalu masih kurang memuaskan. Oleh karena itu saran yang dapat dijabarkan peneliti dalam meningkatkan pembelian ulang antara lain: (a) Meningkatkan layanan after sales service bagi konsumen dengan meningkatkan kualitas SDM yang bertugas di customer service agar dapat memberikan layanan yang cepat dan profesional. (b) Sering melakukan observasi di pasar, atas produk maupun pesaing, sehingga Kaskus dapat memberi penawaran terbaik. (c) Membuat fitur pembayaran ongkos kirim yang customized bagi konsumen yang membeli produk barang lebih dari satu jenis dalam jangka waktu pengiriman barang yang sama. (d) Memberikan solusi dengan reward ataupun bentuk kompensasi lainnya bagi konsumen yang kecewa ataupun tidak puas karena layanan ataupun produk yang dibeli secara nyata dan tidak berbelit-belit.

\section{DAFTAR PUSTAKA}

Cheskin Research. (1999). E-commerce TrustStudy. A Joint Research Project by Cheskin and Studio Archtype/Sapient. Diakses tanggal 20 Juli 2012 dari http://www.studioarchtype.com/cheskin

Corbitt, B., Lawrence, E., Tidwell, A., Fisher, J. and Lawrence, J., (2003). Internet Commerce: Digital Models for Business-Chinese Edition. Brisbane: John Wiley \& Sons, Australia Ltd

Grabosky, P., G. Duffield. (2001). Red flags of fraud. Trends \& Issues. 200. Diakses tanggal 23 Juli 2012 dari http://www.popcenter.org/problems/credit_card_fraud/PDFs/Grabosky\&Duffield.pdf

Hyun Shik Yoon. (2009). Journal Focusing On Conusmer to Consumer Trust in Electronic Commerce With Age and Gender Factors. University of Missouri

Jones, K., Leonard, L.N.K. (2008). Trust in consumer to consumer electroniccommerce. Journal of Information and Management, (45), 88-95.

Kotler P. (2009). Marketing Management, Prentice Hall, 11 edition

Malhotra, Neresh K. (2007). Marketing research an Applied Orientation 5th Ed. New Jersey; Pearson Education 
Morgan, R., Hunt, S. (1994). The commitment - trust theory of relationshipmarketing. Journal of Marketin, 58, 20-38.

Pavlou A, Gefen, D. (2002). Building effective online market places with institutin based trust. Information System Research, 15, 37-59

Peter, J. Paul dan Olson, Jerry C. (2000). Perilaku konsumen dan strategi pemasaran. Jakarta: Erlangga

Rao, H.R., Salam, A.F., DosSantos, B. (1998). Marketing and the Internet. Communication of the ACM, 41(3), 32-34.

Schmidt, M., Chen, Q. J., Phan, D. D., Arnett, K. P. (2009). Security Perceptions of E-commerce Users. Journal of Internet Commerce, 8 (1-2), 44-57

Schubert, Petra dan Mark Ginsburg. (1999). Virtual Communities of Transaction: The Role of Personalization in Electronic Commerce. in Twelfth International Bled Electronic Commerce Conference. Bled, Slovenia.

Sekaran, Uma. (2006). Metode Penelitian untuk Bisnis. Jakarta : Salemba Empat

Yoon, Sung-Joon. (2002). The Antecendents and Consequences of Trust in Online Purchase Decisions. Journal of Interactive Marketing, 47 